\title{
PREVENTIIA BOLII DIAREICE ACUTE DATORATĂ ROTAVIRUSULUI
}

\author{
Oana Falup Pecurariu' \\ 'Spitalul Clinic de Copii Brașov, Facultatea de Medicină, Universitatea „Transilvania” Brașov
}

\begin{abstract}
A vaccine against acute diarrhoea disease determined by rotaviruses can prevent a big amount of hospitalisations and consultings of childrens, reducing the direct and indirect costs. Trials proved the eficiency of the vaccine administrated together with the other vaccines in imunisation schemes, with reduced reverse effects.
\end{abstract}

Key words: viral diarhoea disease, rotavirus, monovalent vaccine, quadrivalent vaccine, pentavalent vaccine.

Rezumat: vaccinarea împotriva bolii diareice acute determinate de rotavirusuri poate preveni un număr mare de internări şi consultații la copii, reducând costurile directe şi indirecte. Trialurile au dovedit eficiența vaccinului coadministrat cu celelalte vaccinuri în schemele de imunizare, cu efecte adverse reduse.

Cuvinte cheie: boala diareică virală, rotavirus, vaccin monovalent, tetravalent, pentavalent.

\section{Introducere}

Rotavirusul este principalul agent etiologic al bolii diareice virale la copil [1]. Aproximativ 80\% dintre copii vor experimenta cel puțin un episod de diaree cu rotavirus înaintea vârstei de 5 ani. Aceasta înseamnă că în SUA vor exista 410.000 de consultații pe an, 250.000 de vizite la urgență și în jur de 60.000 de spitalizări, toate datorate rotavirusului.

În anul 2008 CDC a publicat un raport legat de impactul vaccinării antirotavirale asupra evoluției sezoniere a virusului, care a demonstrat o incidență scăzută a consultațiilor pentru diareea virală cu mai mult de 50\% [1].

Pentru țările europene OMS arată un număr de 6550 de decese anual datorate bolii rotavirale, cu posibile valori mai ridicate în țările sărace și extrem de sărace [2].

Datele actuale legate de prevenția bolii diareice acute determinate de rotavirus evidențiază două momente importante din punct de vedere epidemiologic și anume înainte și după implementarea vaccinării.

\section{Patogeneza infecției rotavirale}

Rotavirusul infectează intestinul subțire, unde eliberează enterotoxine și distruge epiteliul de suprafață, ducând la distrucții masive și eliberarea de cantități masive de virusuri [2]. Perioada de incubație este de mai puțin de 48 de ore.

Spectrul de manifestări clinice este extrem de larg: de la manifestări ușoare fără deshidratare, până la manifestări cu diaree și deshidratare severă [3].

Principalele manifestări clinice sunt temperatura, scaunele, apoase, vărsăturile asociate sau nu deshidratării.

Rotavirusul este un virus cu ARN, care a fost detectat în sânge, diverse organe, dar și în lichidul cerebro spinal [4]. Virusul face parte din familia Reoviridae. Capsida virală este acoperită de trei stra- 
turi, care au unsprezece segmente dublu catenare de ARN. Stratul extern are două proteine structurale VP7, sau proteina G și VP4 proteina P. Ele definesc serotipurile virale și au fost cele care au determinat dezvoltarea vaccinurilor [5].

Deoarece genele care codează proteinele se pot segrega separat, cel puțin teoretic, s-a dezvoltat un sistem de tipare, 14VP7 și 20VP4 fiind descriși inițial. Există lanțuri care circulă mai frecvent și anume G1P1A, G2P1 B,G3P1 A și G4P1A.

Mai multe specii de animale pot $f i$ afectate de infecția cu rotavirus [6].

Copilul va putea fi infectat de mai multe ori în decursul vieții sale, cea mai severă îmbolnăvire rămâne prima, care de multe ori are loc după vârsta de trei luni și care evoluează cu deshidratare severă [7].

Rotavirusurile vor fi eliberate în număr imens de $10^{12}$ particule virale per gram de scaun în scaunele celor infectați înainte, dar și multe zile după terminarea diareei [8].

Este nevoie de foarte puține particule infectante, iar răspândirea în cadrul aceleași familii este obișnuită. Adultul poate fi contaminat, însă va dezvolta rar boala, deoarece are imunitate dobândită. Transmiterea prin apa contaminată este rară, dar nu imposibilă [9].

Există un model de sezonicitate, cu activitate care începe în decembrie și se sfârșește în aprilie mai [10].

Determinarea de laborator este extrem de utilă, atât pentru ghidarea terapiei, cât și pentru realizarea programelor de supraveghere. Cea mai utilizată metodă este cea enzimatică prin EIA, care are kit-uri ce diagnostichează extrem de rapid infecția. Alte tehnici mult mai sofisticate utilizează PCR, dar sunt și mult mai costisitoare.

\section{Dezvoltarea vaccinului}

Cercetările au demarat în anul 1970. Primul candidat a fost vaccinul monovalent derivat dintrun singur lanț din gazda bovină sau Rhesus. Primele trialuri cu o singură doză au arătat ca vaccinul ar fi sigur şi eficient în prevenție [11]. Studiile de evaluare au demonstrat că acest vaccin nu oferea protecție decât pentru un singur lanț.

Vaccinurile multivalente au fost dezvoltate începând cu 1985, utilizând reasortarea genică [12].

Primul vaccin lansat oficial a fost Rotashield, care era un vaccin tetravalent derivat din lanțuri Rhesus cu trei doze de administrat la două, patru şi la şase luni [13]. A fost retras de pe piața americană la mai puțin de un an, întrucât s-a constat o creştere a numărului de invaginaţii intestinale, care au apărut după administrarea sa. Riscul mare de invaginație a fost la 3-14 zile de la administrarea primei doze de vaccin, cu risc mai mic la cea de a doua doză [14].

Vaccinul pentavalent Rotateq a fost lansat oficial în SUA în anul 2006 şi conține 5 lanţuri reasortante de rotavirus, dezvoltate din lanţuri de rotavirus uman şi bovin.

Lanțurile exprimă una dintre proteinele exterioare ale capsidei G1, G2, G3, G4 din lanțul parental uman, iar a cincea exprimă ataşamentul proteic P1A(8) din lanţul parental uman şi al capsidei proteice G6 din lanțul parental bovin. Nu s-a stablit o relație strictă între răspunsul anticorpilor rotavirali la vaccinare şi protecția împotriva diareei cu rotavirus, seroconversia a fost însă crescută la cei care au primit vaccinul [15].

Eficiența vaccinului a fost evaluată în două trialuri de fază III. În cadrul acestor trialuri nu a fost acceptată administrarea de vaccin antipoliomielitic oral. Studiul a cuprins 4512 de copii din SUA şi Finlanda. Eficiența RV5 împotriva G1-G4 a fost de 74\% în primul sezon de după vaccinare, iar împotriva gastroenteritei severe a fost de $98 \%$. Numărul de consultații a fost redus şi el de asemenea cu $86 \%$. Alimentația naturală nu determină modificarea eficienței dozei a treia de vaccinare.

Datorită posibilelor efectelor secundare, vaccinul a putut fi bine evaluat. Numai şase cazuri de invaginația au apărut la cei vaccinați [16]. Decesul nu a înregistrat rate crescute față de placebo. Rata de boală diareică acută a apărut la $0,2 \%$ dintre cei vaccinați după prima doză de vaccin. Prematurii vaccinați nu au avut efecte adverse remarcabile [17]. 
Vaccinul monovalent Rotarix RV1 a fost aprobat în anul 2008 pentru a fi utilizat în SUA și conține un lanț uman de rotavirus tip G1P1A8. A fost dezvoltat dintr-o tulpină umană izolată în Cincinnati, Ohio, în anul 1988 [18].

Seroconversia a fost definită ca și apariția de anticorpi tip IgA antirotavirali postvaccinare în serul sugarilor care era negativ pentru anticorpi tip IgA la rotavirus. După cea de a doua doză de vaccin 86,5\% dintre vaccinați s-au convertit serologic comparativ cu 6,7\% în grupul placebo.

Un alt studiu a dovedit eficiența acestui vaccin coadministrat cu celelalte vaccinuri în schemele de imunizare acceptate în SUA [19].

Rotarix a fost evaluat în două trialuri mari în America latină și în Europa. În trialul din America latină s-a utilizat o scală Vesikari care cuprindea 20 de puncte, un total peste 11 fiind considerat episod de diaree severă [19]. În acest trial eficiența RV1 împotriva gastroenteritei severe a fost de 84,7\% după două doze administrate până la vârsta de două luni. Eficiența a fost comparabilă și după utilizarea scalei Vesikari, fiind de $84.8 \%$. Nu a fost evaluată eficiența vaccinului împotriva oricărei forma de diaree, indiferent de severitate. În Europa trialul a fost efectuat pe un număr de 3.874 de sugari și s-a umărit prevenția oricărui tip de diaree indusă de rotavirus, de orice fel de severitate, care s-a evaluat la 2 săptămâni după administrarea celei de a doua doze de vaccin. Eficiența a fost de $87,1 \%$ după primul sezon de vaccinare, iar eficiența împotriva diareilor severe a fost de 95,8\%. S-a mai observat eficiență împotriva tulpinilor non G1 [20].

\section{Reacții adverse post vaccinare}

Invaginația a fost evaluată la 63.225 sugari și nu s-a observat nici un risc la cei la care s-a administrat cel puțin o doză față de grupul placebo.

Pe o perioadă de până la 30 de zile post vaccinare, în șapte cazuri din 31.673 de sugari s-a observat apariția invaginației față de șapte în grupul de placebo. În cursul întregului studiu mortalitatea a fost de $0,19 \%$, decesele fiind datorate pneumoniei.

Alte efecte adverse, cum ar fi diareea sau deshidratarea, au apărut la 0,07\%, respectiv 0,06\% dintre cei care a primit vaccinul [20].

În trialul european nu s-au raportat decese, iar între efectele adverse majore, pneumonia a fost pe primul loc. Pentru prematuri trialul arată o tolerabilitate bună, însă se așteaptă date noi.

Există câteva recomandări noi legate de vaccinul Rotarix. Este necesară administrarea de doze la 2 și la 4 luni. Vârsta maxim admisă pentru doza I este de 14 săptămâni și 6 zile față de 12 săptămâni. Vârsta maxim admisă pentru ultima doză este de 8 luni și 0 zile.

Intervalul minim între vaccinări este de 4 săptămâni. Se poate administra cu orice produs sau derivat sangvin, urmându-se exact schema de vaccinare.

Recomandarea Academiei Americane de Pediatrie este ca vaccinarea să fie efectuată cu același tip de vaccin, oricând este posibil. Contraindicații au cei cu alergii cunoscute la o doză anterioară.

\section{Analize de cost-eficiență a vaccinării}

Au fost efectuate în diferite țări, utilizându-se un model analitic prin care s-a dovedit că utilizarea vaccinării este în măsură să prevină un mare număr de vizite la spital [21]. În Vietnam evaluarea eficienței vaccinării a arătat că ar putea fi prevenite $67 \%$ dintre diareile din primii 5 ani de viață [22]. De asemenea a fost evaluată eficiența vaccinării concomitente cu alte vaccinuri, titrurile de anticorpi fiind crescute, dovedindu-se astfel siguranța administrării concomitente. Administrarea concomitentă cu vaccin antipolio oral a fost foarte bine tolerată și este înalt eficientă [23, 24]. 
Referințe

1. Rayani A, Bode U, Habas E, et al. Rotavirus infections in a paediatric oncology patients a matched-pairs analysis. Scand J Gastroenterol 2007;42:81-7.

2. Glass RI, Parashar UD, Bresee JS at al. Rotavirus vaccines: current prospects and future challenges. Lancet 2006;368:323-32.

3. Carlson JAK, Middleton PJ, Syzmanski MT et al. Fatal rotavirus gastroenteritis: an analysis of 21 cases. Am J Dis Child 1978;132:477-9.

4. Glass RI, Bresee J, Jiang B et al. Rotavirus and rotavirus vaccines. Adv Exp Med Biol 2006;582:45-54.

5. Estes MK, Cohen J. Rotavirus gene structure and function. Microbiol Rev 1989;53:410-49.

6. Gentsch JR, Woods PA, Ramachandran M et al. Review of $G$ and P typing results from a global collection of rotavirus strains: implications for vaccine development. J Infect Dis 1996;174:S30-36.

7. Raul Velazquez, Calva JJ, Lourdes Guerrero $M$ et al. Cohort study of rotavirus serotype patterns in symptomatic and asymptomatic infections in Mexican children. Ped Inf Dis J 1993;12:54-61.

8. Bishop RF. Natural history of human rotavirus infection. Arch Virol 1996;12:119-28.

9. Bresee JS. Rotaviruses. In Principles and practice of pediatric infectious diseases. St.Louis, MO: Churchill Livingstone 2008,1078-81.

10. LeBaron CW, Lew J, Glass RI et al. Annual rotavirus epidemic patterns in North America: results of a five year prospective survey of 88 centers in Canada, Mexico and United States. JAMA 1990;264:983-8.

11. Vesikari T, Isolauri E, Delem A, D'Hondt E et al. Immunogenicity and safety of oral attenuated bovine rotavirus vaccine strain RIT 4237 in adults and young children. Lancet 1983;2:807-11.

12. Midthun K, Greenberg HB, Hoshino $\mathrm{Y}$ et al. Reassortant rotaviruses as potential live rotavirus vaccine candidates. J Virol 1985;53:949-54.

13. CDC. Rotavirus vaccine for the prevention of rotavirus gastroenteritis among children. MMWR 1999:48.

14. Murphy TV, Gargiullo PM, Massoudi MS et al. Intussusception, rotavirus, and oral vaccines: summary of a workshop. Pediatrics 2002;54:110.

15. Block SL, Vesikari T, Goveia MG et al. Efficacy, immunogenicity and safety of a pentavalent human-bovine WC3 reassortant rotavirus vaccine at the end of shelf life. Pediatrics 2007;119:11-18.

16. Vesikari T, Matson DO, Dennehy P et al. Safety and efficacy of a pentavalent human bovine WC3 reassortant rotavirus vaccine. N Engl J Med 2006;354:23-33.

17. Goveia MG, Rodriguez ZM, Dallas MJ, et al. Safety and efficacy of the pentavalent human-bovine WC3 reassortant rotavirus vaccine in healthy premature infants. Ped Inf Dis J 2007;26:1099-104.

18. Bernstein DI, Smith VE, Sherwood JR et al. Safety and immunogenicity of live attenuated human rotavirus vaccine. Vaccine 1998;16:381-387.

19. Ruiz Palacios GM, Perez- Schael I, Velazquez FR et al. Safety and efficacy of an attenuated vaccine against severe rotavirus gastroenteritis. N Engl J Med 2006;354:11-22.

20. Food and Drug Administration. Rotarix clinical review. Rockville MD: US Department of Health and Human Services, Food and Drug Administration, 2008, www.fda.gov/cber/products/rotarix/rotarix031008 rev.pdf.

21. Zomer TP, vanDuynhoven YT, Mangen MJ. Et al. Assessing the introduction of universal rotavirus vaccination in the Netherlands, Vaccine 2008, 26:3757-3764.

22. Kim SY, Goldie SJ, Salomon JA. Cost effectiveness of Rotavirus vaccination in Vietnam. BMC Public Health 2009,21:9-29.

23. Ciarlet M, Sani-Grosso R, Yuan G et al. Concomitant use of the oral pentavalent human bovine reassortant rotavirus vaccine and oral poliovirus vaccine. Ped Inf Dis J 2008;27:874-80.

24. CDC. Rotavirus surveillance worldwide, 2001-2008. MMWR Morb Mortal Wkl Rep. 2008;57:12551257. 